\title{
Tuotos, hedelmällisyys, hoidot ja poistot tavanomaisissa ja luomulypsykar- joissa 1998 - 2002
}

Kristiina Dredge ${ }^{1}$, Olli Peltoniemi ${ }^{1}$, ja Päivi Rajala-Schultz ${ }^{2}$

${ }^{1}$ Helsingin yliopisto, eläinlääketieteellinen tiedekunta, Saaren yksikkö, Pohjoinen pikatie 800, 04920 Saarentaus, etunimi.sukunimi@helsinki.fi

${ }^{2}$ The Ohio State University, Department of Veterinary Preventive Medicine, 1900 Coffey Road, 203 Sisson Hall, Columbus 43210, Ohio, USA

\section{Tiivistelmä}

Tämän tutkimuksen tavoitteina oli 1) määritellä lypsykarjojen tuotokseen ja hedelmällisyyden hallinnan tunnuslukuihin vaikuttavat karjatason muuttujat tavanomaisessa ja luomutuotannossa, 2) kuvailla lehmillä yleisimpien sairauksien hoitoprosentteja ja poistonsyitä, ja 3) vertailla eroja tuotantosuuntien välillä. Tutkimusaineistona käytettiin 1226 tavanomaisen ja 109 luomutilan karjantarkkailutietoja vuosilta 1998-2002. Aineistoa analysoitiin lineaaristen mixed-mallien avulla.

Karjojen keskituotos kasvoi tarkastelujaksolla luomutuotannossa 6822:sta 7422:een, ja tavanomaisessa 7426:sta 8206 kiloon, ollen luomukarjoissa keskimäärin 688 kg alhaisempi. Keskituotoksesta muualle kuin meijeriin päätyi keskimäärin 9,3\%. Poistettujen lehmien elinikäistuotos kasvoi luomutuotannossa keskimäärin 18 491:stä 19 849:ään ja tavanomaisessa 19 751:stä 22073 kiloon. Luomutuotannossa se oli keskimäärin $2050 \mathrm{~kg}$ tavanomaista alhaisempi.

Lehmien poistoiässä tai poiston syissä ei ollut merkittäviä eroja tuotantosuuntien välillä. Erot hedelmällisyyden hallinnan tunnusluvuissa tuotantosuuntien välillä olivat merkityksettömiä. Luomukarjoissa kaikkien tarkasteltujen sairauksien hoitoprosentit olivat tavanomaisia alhaisempia.

\section{Asiasanat}

lypsykarja, tuotos, hedelmällisyys, sairaudet, luomukotieläintuotanto 


\section{Johdanto}

Suomalaisen elintarviketuotannon tavoitteena on tuottaa ruokaa, joka täyttää laadun kriteerit monella eri osa-alueella. Tuotantoeläinten terveys ja hyvinvointi, sekä maatalousyrittäjän taloudellinen hyvinvointi ovat osa lopputuotteen kokonaislaatua. Luomutuotanto on yksi lypsykarjatilan erikoistumismahdollisuuksista. Se on lisääntynyt monissa Euroopan maissa. Luomueläinten hoito poikkeaa tavanomaisesta. Tällä voi olla vaikutusta eläinten tuotokseen, terveyteen ja hyvinvointiin, sekä tilan tuotannon talouteen. Luomukotieläintuotantoa koskevaa, pohjoismaisiin tuotanto-olosuhteisiin sovellettavaa, tieteellisesti validia tutkimustietoa on toistaiseksi saatavilla vähän.

Tämän tutkimuksen päätavoitteena oli määritellä lypsykarjojen tuotokseen ja hedelmällisyyden hallinnan tunnuslukuihin vaikuttavat karjatason muuttujat tavanomaisessa ja luomutuotannossa, sekä vertailla eroja tuotantosuuntien välillä. Tavoitteena oli myös kuvailla lehmillä yleisimpien sairauksien hoitoprosentteja ja poistonsyitä.

\section{Materiaali ja menetelmät}

Tutkimusaineistona käytettiin karjantarkkailutietoja vuosilta 1998-2002. Tutkimukseen valittiin kaikki kyseisen ajanjakson tarkkailussa mukana olleet luomu-, ja otos tavanomaisia lypsykarjatiloja. Aineistosta poistettiin selvästi virheelliset tiedot. Kaikkiaan tarkasteltiin 1226 tavanomaista ja 109 luomutilaa. Tuotosta ja hedelmällisyyden hallinnan tunnuslukuja mallinnettiin lineaarisen regressiomallin avulla, jossa karja oli satunnaismuuttujana ja vuosi selittävänä tekijänä. Hoitoprosentteja ja poiston syitä tarkasteltiin pääosin kuvailevasti.

\section{Tulokset}

Tutkimukseen osallistuvista karjoista noin $90 \%$ oli parsinavetassa ja $10 \%$ pihatossa. Keskilehmäluku kasvoi luomutuotannossa nopeammin; mediaanin muutos 1998-2002 oli 5,1 luomu- ja 2,3 tavanomaisessa tuotannossa. Vuonna 2002 keskimääräisellä luomutilalla oli 21,3 ja tavanomaisella 18,8 lehmää.

Karjojen keskituotos kasvoi tarkastelujaksolla luomutuotannossa 6822:sta 7422:een, ja tavanomaisessa 7426:sta 8206 kiloon. Luomukarjoissa se oli keskimäärin $688 \mathrm{~kg}$ alhaisempi kuin tavanomaisissa, mutta tuotantosuunta ja vuosi selittivät karjojen välisestä vaihtelusta ainoastaan 4\%. Keskituotoksesta päätyi muualle kuin meijeriin keskimäärin 9,3\%. Poistettujen lehmien elinikäistuotos kasvoi luomutuotannossa keskimäärin 18 491:stä 19 849:ään ja tavanomaisessa 19 751:stä 22073 kiloon. Luomutuotannossa se oli keskimäärin $2050 \mathrm{~kg}$ tavanomaista alhaisempi. Lehmien poistoiässä tai poiston syissä ei ollut merkittäviä eroja tuotantosuuntien välillä.

Erot hedelmällisyyden hallinnan tunnusluvuissa tuotantosuuntien välillä olivat merkityksettömiä. Poikimaväli oli luomutiloilla 1,4 päivää pitempi, mutta ero ei ollut tilastollisesti merkitsevä. Lepokausi oli luomutuotannossa keskimäärin 5 päivää tavanomaista pitempi, mutta siemennyksiä/poikiminen oli vähemmän. Luomukarjoissa kaikkien tarkasteltujen sairauksien hoitoprosentit olivat tavanomaisia alhaisempia. Luomukarjoissa oli merkitsevästi enemmän niitä, joilla ei ollut hoidettu yhtään utaretulehdustapausta. 